\title{
COVID-19 and Its Implications to the Assessment of Sustainable Palm Oil Supply Chain Management: An Indonesian Perspective
}

\author{
Nusrat Hafiz ${ }^{1,2 *}$, Khairunnisa Mohd Azmi ${ }^{1}$, Danjuma Tali Nimfa ${ }^{3}$, \\ Ahmad Shaharudin Abdul Latiff ${ }^{1}$ and Sazali Abd Wahab ${ }^{1}$ \\ ${ }^{1}$ Putra Business School, Seri Kembangan, Malaysia, ${ }^{2}$ BRAC Business School, BRAC University, Dhaka, Bangladesh, \\ ${ }^{3}$ Department of Business Administration, Faculty of Management Sciences, University of Jos, Jos, Nigeria
}

OPEN ACCESS

Edited by:

Halima Begum,

Universiti Utara Malaysia, Malaysia

Reviewed by:

Sharmila Saren,

Government General Degree

College, India

Chye Ing Lim,

Curtin University Sarawak, Malaysia

*Correspondence:

Nusrat Hafiz

nusrat.phd_mgt18@

grad.putrabs.edu.my

Specialty section:

This article was submitted to

Sustainable Supply Chain

Management

a section of the journal

Frontiers in Sustainability

Received: 09 July 2021 Accepted: 30 November 2021

Published: 04 January 2022

Citation:

Hafiz N, Azmi KM, Nimfa DT,

Latiff ASA and Wahab SA (2022) COVID-19 and Its Implications to the Assessment of Sustainable Palm Oil

Supply Chain Management: An Indonesian Perspective.

Front. Sustain. 2:738985 doi: 10.3389/frsus.2021.738985
Motivated by the low sustainability index and pressure to meet the global demand for eco-friendly crude palm oil (CPO) in the pandemic-ridden environment, this research aims to investigate the implications of the COVID-19 pandemic to assess the drivers of sustainable supply chain management (SSCM) of the Indonesian CPO sector to tackle supply chain disruptions. To achieve this aim, the study seeks to determine the sustainability drivers to accommodate the pandemic-ridden environment and if sustainability indicators can help improve the supply chain management of the CPO sector. A methodology is divided into two interrelated parts: first, based on a careful review of extant literature of the CPO sector and sustainable supply chain in the light of pandemic. The proposed methodology is then tested using the response data of 108 oil mills' representatives collected through survey questionnaires and analyzed using statistical tools of reliability, distribution, Kaiser-Meyer-Olkin (KMO), Confirmatory Factor Analysis (CFA), and diagnostic tests of CFA. The findings designate the environmental costs, rapidity, and adaptability as core economic indicators; the social and workforce development, health, and safety workforce development and consumer issues as crucial social indicators; while energy and material efficiency, management of waste and emissions, and sustainable suppliers as the best environmental indicators. This study provides a holistic platform on the implications of the pandemic to assess the SSCM of the CPO sector. These findings are expected to aid the industrial managers in employee skills and health protocols, customer service, and environmental management. The study is also anticipated to guide the supply-chain partners and government policymakers to take initiatives on SSCM in the context of the pandemic.

Keywords: assessment, COVID-19, palm oil, sustainable, supply chain management

\section{INTRODUCTION}

The pressure to meet the global demand for eco-friendly and equitable crude palm oil (CPO) by Indonesia that has already been condemned for its low sustainability index of $\mathrm{CPO}$ (Papilo et al., 2018), escalates the gravity to adopt sustainable production of CPO by Indonesia (Khatun et al., 2017). The tropical produce, Oil palm (OP), has met the growing demand for bio-energy, cosmetics, food ingredients, and animal feed globally. The CPO industry faces several threats: deforestation, 
biodiversity loss, environmental degradation, pollution, and scarce environmental know-how. Recently, the entire supply chain has been adversely affected by the COVID-19 pandemic (Ivanov and Das, 2020; Kilpatrick and Barter, 2020), which caused severe health, labor market, and economy worldwide. The crises exacted the businesses to reconsider their global supply chain strategy to endorse and hasten various sustainable measures to combat a disruptive business environment (Ivanov, 2020a; Remko, 2020) of the covid-ridden economy.

In order to meet the sustainability needs, the OP companies need to adopt the highest sustainability approaches (Sajjad et al., 2020) and at the same time align with the stakeholders' conjecture and expectations. To explore new drivers to support the supply chain, the supply chains need to make necessary changes in the management to enhance their resilience capabilities and competitiveness (Hobbs, 2020). Previous studies revealed the gravity of adopting a sustainable supply chain management (SSCM) crucial for an industry's survival. Zeng et al. (2017) formulated a sustainable supply chain framework in a circular economy to accommodate the bureaucratic pressure from legal, economic, and social bodies. Li and Mathiyazhagan (2018) explored the key sustainable supply chain determinants to boost the sustainability performance of the automobile sector. According to Munny et al. (2019), customer needs and employees' health and safety, wages, and other benefits the effective social sustainability practices (Karmaker et al., 2021). Gupta et al. (2020) explored the challenges of supply chain sustainability innovation and offered solutions and strategies to adopt sustainable supply chains.

Unfortunately, the extant literature on assessing sustainable supply chain drivers is not adequate for the present context as the novel and unique COVID-19 pandemic with anonymous attributes has changed old assumptions about supply chain sustainability (Choi, 2020; Ivanov, 2020a). Also, studies emphasizing all three dimensions, namely environment, economic, and social transformations in diverse sustainability challenges, are inadequate. In addition, despite several calls for research on OP development and transformations concerning a particular supply chain management and the impact of COVID-19, no research was conducted. Thus, this present study seeks to fulfill the research gaps by assessing the implication of pandemic on sustainable SCM of the CPO sector. This study has two objectives. First, to find the sustainability drivers to accommodate the pandemic-ridden environment. Second, to investigate if sustainability indicators can help improve the sustainability of the supply chain management of the CPO sector.

The present study provides evidence from Indonesia, taking representatives of the OP mills as a unit of analysis, where no significant research has been conducted. It may help the researchers, policymakers, and practitioners of OP-producing

Abbreviations: CPO, Crude Palm Oil; SSCM, Sustainable Supply Chain Management; KMO, Kaiser-Meyer-Olkin; CFA, Confirmatory Factor Analysis; FFB, Fresh fruit branches; OP, Oil Palm; TBL, Triple Bottom Line; ECS, Economy Sustainability; SS, Social Sustainability; ENS, Environmental Sustainability; KPI, Key Performance Index; COVID-19, Coronavirus Disease 2019; NGOs, Nongovernmental organizations. countries by offering insights on the subject. The study aims to open up the corridors to assess the sustainability of equitable palm oil by presenting a comprehensive analysis. It is expected that there might be new findings on the sustainable SCM of OP, especially on the issues of implications of the COVID19 pandemic.

The remainder of this study is organized as follows. Section Literature Review details the theoretical background to develop the skeleton of the analysis. Section Methodology discusses the sampling methods and measurement procedures. The study results are presented in section Results. Findings and discussion are elaborated in the subsequent sections, which are Findings and Discussion respectively. Section Conclusion concludes the study.

\section{LITERATURE REVIEW}

\section{Oil Palm (OP) Supply Chain Structure}

Oil palm (OP), with the scientific title of Elaeis guineensis, stands as one the most promising global oil crops that covers almost $40 \%$ of the exported volume of vegetable oils. Palm oils and their downstream harvests have been profoundly imported all over the world. Palm oils are widely consumed by more than three billion people of Asia as a primary dietary constituent. Palm kernel oil has also been popular for non-edible purposes, such as cleaning, sanitizing, cleanings, hygiene, and personal care products, such as cleansing agents, lathers, and surface cleaners (Central Point of Expertise on Timber, 2015). OP is crucial to the economies of the two South East (SE) Asian countries, namely Indonesia and Malaysia, from which it has been exported worldwide in the forms of oil, food additive, and other derivatives (Ommelna et al., 2012). Key locations of global oil palm cultivation are highlighted in (Table 1).

Regardless of the local or global level, the entire supply chain is affected and faces challenges in ensuring logistics and manufacturing operations (Statista, 2020). Businesses have been badly damaged by the pandemic named COVID-19 with its deadly, transmittable, and unpredicted symptoms. This caused severe disorders to human lives and the circular economy (Klande et al., 2019). The global supply chain is faced with considerable risk, and trading and distribution activities have been reduced significantly. The sprawl of COVID-19 affected most countries and territories with an increasing rate of active cases and deaths (Farooq et al., 2021). Though during early2020, the lockdown initially affected the trade of the vital OP importers, the OP supply chain has been demonstrating resilience to the early shock of lockdown and continued transporting millions of tons of palm oils with minimum disruption from the major importing hubs of South-East Asia and Europe. While OP supply chains of Indonesia were comparatively less affected by the pandemic followed by localized lockdown and insufficient workers, a $10 \%$ reduction in palm oil production is predicted in the upcoming years from the previous year (MPOC, 2020).

\section{Sustainable Supply Chain and COVID-19}

Sustainability involves the notion of how humans should carry responsibility for the natural environment and future generations (Clark, 2007). Sustainable development seeks to cover the needs 
of the existing cohort without negotiating the capacity of the impending cohorts (World Commission on Environment Development, 1987). As sustainability is achievable by addressing social, environmental, and financial objectives in the supply chain (Mitchell and Walinga, 2017; Raut et al., 2017), a sustainable supply chain will be better able to minimize the adverse effects of supply chain operations and enhance the performance and value of supply chain management (Vargas et al., 2018). Other benefits of adopting sustainability in the supply chain would be to supplement the brand identity and socially conscious image. It also reduces time and expense associated with potential environmental pollution and other damages. Companies are eventually better off (Bai et al., 2019).

Unfortunately, neither the need to adopt sustainability has been recognized nor the competency required for administering sustainability practices has been adequate by the firms of the developing economies (Luthra et al., 2017). Therefore, it is imperative to adopt sustainability in the supply chain to corroborate various prospects for sustainable performance of the businesses. The COVID-19 pandemic has left unfavorable effects on the sustainability of value chains worldwide (Govindan, 2018) and created substantial detrimental effects on sales revenue, return on investment, procurement strategies, materials supply, logistics service (Bag et al., 2020; Majumdar et al., 2020; Sharma et al., 2020), production, distribution, or logistics (Ivanov, 2020a). Following the interruption and bottleneck of the supply chain caused devastating consequences (Ivanov, 2020b; Karmaker et al., 2021).

It is not surprising that the existing supply chain strategies and practices designed for a regular operation in the supply chain will not be practical and feasible to tackle a global pandemic like COVID-19. The supply chain managers need to reconsider designing their strategies and practices to accommodate the pandemic era. The businesses are wrestling with formulating a supply chain incorporating the features of sustainability (Sharma et al., 2020) and extra-resilient approaches (de Sousa Jabbour et al., 2020) to combat the challenges offered by the COVID19 consequences. With the gigantic outburst of COVID-19 continuing worldwide, various organizations shift to workfrom-culture, laboratories constantly work to innovate vaccines, medications, and healthcare facilities with relentless research.

Adoption by the affected companies in emerging economies of socially distanced working environments, community lockdown, isolation (Majumdar et al., 2020) and adequate personal protective equipment (PPE), ventilators, masks, face shields, and hand sanitizers (Sharma et al., 2020; Karmaker et al., 2021) to prevent the transmission of COVID-19 disease is inadequate. The terrible health hazards, unemployment, and economic turmoil have triggered economic and social sustainability trials during the pandemic (Majumdar et al., 2020). It is a timely need to rethink a viable resistance level of the supply chain (Ivanov and Dolgui, 2020) to halt the disintegration of the economy.

\section{Sustainability Drivers of SCM in the Context of COVID-19}

Supply Chain Management (SCM) refers to ensuring a synthesized approach across the supply chain, starting from sourcing raw materials, constructing or assembling a product, dispatching it to retail outlets, and actual consumers' end. The oil millers need to restructure their supply chain practices with "tailor-made indicators to enhance sustainable supply chain management performance, especially in the pandemic era (Kusrini and Maswadi, 2021). The key drivers of SSCM ultimately benefit the stakeholders from seven sectors: oil palm producers, processors or traders, consumer goods manufacturers, retailers, banks/investors, and environmental and social nongovernmental organizations (NGOs).

In the research of Kusrini and Primadasa (2018), the weighted key performance indicators (KPI) of the SSCM palm oil industry have been identified by combining literature reviews. It is imperative to improve sustainable supply chain management to remain competitive in the COVID-ridden business environment and enhance performance (Sutawidjaya et al., 2021). Proactively detecting disruptions and quick remedial actions can allow industries to lower the impact of current and future shocks (Farooq et al., 2021). Addressing the consequences of diseases under a unanimous framework in the current timeline can be the first step. Some 26 published literature have been observed relating sustainable supply chain management to formulate the essential indicators to assess the performance of sustainable supply chain management from economic, social, and environmental dimensions, specially catered to the pandemicridden business environment.

Evolving from sustainability, sustainable supply chain management (SSCM) aims at managing the supply chain relationship and the flow of materials and information to maximize operational performance and the profitability of the supply chain. Compared with supply chain management, the sustainability feature in the sustainable supply chain management (SSCM) has more multiple dimensions ensuring long-term profitability without adversely affecting natural systems (Seuring and Müller, 2008).

SSC drivers ensure efficient operational and economic performance, contingency planning implementation in uncertain environments, and availing sustainability practices (Tseng et al., 2019; Sajjad et al., 2020; Karmaker et al., 2021). Acknowledging such drivers would help establish the SSC initiatives for sustainable management of the CPO sector. The espousal of SSC would depend on several critical indicators (drivers) that contribute significantly to a successful implementation. Nevertheless, inadequate attention on sustainability drivers to execute the SSC has been exhibited (Munny et al., 2019). Amid the pandemic era, it is crucial to investigate the drivers of sustainability on supply chains that will enhance the post-covid performance of the CPO sector. The essential drivers for SSC well-adapted with pandemic have been mainly derived from the extant literature presented in Table 2.

In Table 2, the ES, SS, and ENS refer to the indicators in the three pillars of sustainability, namely economic, social and environmental, respectively. As an indicator to gauge the organizational improvement (Lim et al., 2015), key performance indicators (a) of sustainable supply chain management (SSCM) of the crude palm oil industry need to be identified. The present study reviews the literature to obtain sustainability KPIs for 
assessing sustainable supply chain management (SSCM) of CPO mills and proposes the following indicators in Table 3.

Given the dynamic business environment, changing customer needs, and economic, environmental, and social concerns, having a sustainable supply chain (SSC) is vital to produce goods and services in the pandemic era (Bag et al., 2020). It is essential to integrate all the industry actors to implement the value of sustainability properly. A sustainable supply chain management (SSCM) can address socio-environmental issues and improve the performance of the community (Kusi-Sarpong et al., 2018) using appropriate KPI indicators, as suggested by past studies.

\section{METHODOLOGY}

The aims of the study are twofold. The first objective is to determine the sustainability indicators of SSCM in line with the

TABLE 1 | Key locations of global oil palm cultivation in 2020 (Statista, 2020).

\begin{tabular}{llcc}
\hline Ranking & Countries & $\begin{array}{c}\text { Palm oil } \\
\text { production }(\mathbf{m t})\end{array}$ & $\begin{array}{c}\text { Palm oil } \\
\text { production 0 }\end{array}$ \\
\hline 1 & Indonesia & 42.5 & 58.8 \\
2 & Malaysia & 18.5 & 25.6 \\
3 & Thailand & 2.8 & 3.9 \\
4 & Colombia & 1.5 & 2.1 \\
5 & Nigeria & 1.0 & 1.4 \\
& Others & 5.9 & 8.2 \\
& Total & 72.3 &
\end{tabular}

pandemic. The second objective is to examine if the sustainability indicators can help improve sustainability in supply chain management to augment the performance in the supply chain. An extensive review of extant literature broadly reached the first objective. A survey among the palm oil mill managers was conducted to reach the second objective of the study.

\section{Screening of Literature}

A literature screening has been carried out using basic phrases, such as: "drivers and indicators for sustainable supply chain adoption" OR "critical factors/motivators/key indicators" AND "sustainability drivers assessment pandemic" OR "investigate sustainable supply chain drivers" OR "impacts/effects of a pandemic on sustainability and sustainable developments of oil

TABLE 3 | KPIs for palm oil industry obtained from literature review.

\begin{tabular}{|c|c|}
\hline KPI & Literature \\
\hline 1. Work in process & Faulkner et al., 2012; Kusrini and Primadasa, 2018 \\
\hline $\begin{array}{l}\text { 2. EHS (env, health and } \\
\text { safety) expenses }\end{array}$ & $\begin{array}{l}\text { Veleva and Ellenbecker, 2001; Bai and Sarkis, } \\
\text { 2014; Kusrini and Primadasa, } 2018\end{array}$ \\
\hline $\begin{array}{l}\text { 3. Rate of Customer } \\
\text { Complaint and } \\
\text { Return }\end{array}$ & $\begin{array}{l}\text { Veleva and Ellenbecker, 2001; Kusrini and } \\
\text { Primadasa, } 2018\end{array}$ \\
\hline 4. Materials usage & $\begin{array}{l}\text { Hall et al., 2012; Sparks, 2014; Kusrini and } \\
\text { Primadasa, } 2018\end{array}$ \\
\hline 5. Acidification Potential & $\begin{array}{l}\text { Veleva and Ellenbecker, 2001; Kusrini and } \\
\text { Primadasa, } 2018\end{array}$ \\
\hline 6. Physical Load Index & Faulkner et al., 2012; Kusrini and Primadasa, 2018 \\
\hline
\end{tabular}

TABLE 2 | Sustainability Indicators to assess SSCM of Oil Palm.

\begin{tabular}{|c|c|c|}
\hline Dimensions & Elements & Publications \\
\hline \multirow[t]{6}{*}{ Economy Sustainability (ECS) } & E $E_{1}$ Environmental Expenses & $\begin{array}{l}\text { Zailani et al., 2012; Morali and Searcy, 2013; Esfahbodi et al., 2016; Rajeev et al., } \\
\text { 2017; Kamble et al., } 2020\end{array}$ \\
\hline & $E_{2}:$ Delivery Speed & Ageron et al., 2012; Bag et al., 2020 \\
\hline & $E_{3}:$ Supply Chain Expense & Ageron et al., 2012; Zimon et al., 2019; Choi, 2020 \\
\hline & $E_{4}:$ Market Competition & $\begin{array}{l}\text { Zailani et al., 2012; Morali and Searcy, 2013; Rajeev et al., 2017; Saeed and Kersten, } \\
\text { 2017; Emamisaleh et al., } 2018\end{array}$ \\
\hline & $E_{5}:$ Product Quality & Ageron et al., 2012; Zailani et al., 2012; Craighead et al., 2020 \\
\hline & $E_{6}:$ Adaptability & Ageron et al., 2012; de Sousa Jabbour et al., 2020; Majumdar et al., 2020 \\
\hline \multirow[t]{5}{*}{ Social Sustainability (SS) } & $S_{1}:$ Social Responsibility & $\begin{array}{l}\text { Azevedo et al., 2011; Zailani et al., 2012; Esfahbodi et al., 2016; Rajeev et al., 2017; } \\
\text { Saeed and Kersten, 2017; Sroufe, 2017; Zimon et al., } 2019\end{array}$ \\
\hline & $S_{2}:$ Health and Safety Measures & Rajeev et al., 2017; Saeed and Kersten, 2017; Emamisaleh et al., 2018 \\
\hline & $S_{3}:$ Employee Development & Saeed and Kersten, 2017; Emamisaleh et al., 2018 \\
\hline & $\mathrm{S}_{4}:$ Human Rights issues & Saeed and Kersten, 2017 \\
\hline & $S_{5}:$ Customer Rights & Rajeev et al., 2017; Saeed and Kersten, 2017 \\
\hline \multirow[t]{5}{*}{ Environmental Sustainability (ENS) } & $N_{1}:$ Energy efficiency & $\begin{array}{l}\text { Zailani et al., 2012; Saeed and Kersten, 2017; Sroufe, 2017; Emamisaleh et al., 2018; } \\
\text { Govindan, 2018; Zimon et al., 2019; Kamble et al., } 2020\end{array}$ \\
\hline & $\mathrm{N}_{2}$ : Material efficiency & Tseng et al., 2015; Saeed and Kersten, 2017 \\
\hline & $N_{3}:$ Water usage & Saeed and Kersten, 2017; Govindan, 2018; Kamble et al., 2020 \\
\hline & $N_{4}:$ Waste management & $\begin{array}{l}\text { Zailani et al., 2012; Tseng et al., 2015; Rajeev et al., 2017; Saeed and Kersten, 2017; } \\
\text { Emamisaleh et al., 2018; Govindan, 2018; Kamble et al., } 2020\end{array}$ \\
\hline & $N_{5}$ : Sustainable Supplier management & Grimm et al., 2014; Rajeev et al., 2017; Saeed and Kersten, 2017 \\
\hline
\end{tabular}


palm sector" OR "scale-up/improving supply chain sustainability in the palm oil industry". For a literature search, databases like Scopus, EBSCO, and Google Scholar have been utilized. Based on the review of extant literature, some sixteen drivers of SSC have been designated.

Also, followed by an extensive literature review, the indicators and sub-elements of SSCM performance were determined. Based on Table 2, for economic dimensions, a total of 6 sub-elements have been chosen for the study, such as environmental expenses, delivery speed, supply chain expense, market competition, product quality, and adaptability. For social dimensions, 5 subelements of social responsibility, health and safety measures, employee development, human rights issues, and customer rights have been determined. Another set consisting of 5 subelements have been decided for the study, including energy efficiency, material efficiency, water usage, waste management, and sustainable supplier management. Based on Table 3, for KPI, the sub-elements have been derived as work-in-process, EHS (environment, health \& safety) expenses, rate of customer complaint and return, materials usage, acidification potential, and physical load index.

\section{Survey}

\section{Study Area and Sample}

The study was to collect opinions of the Indonesian palm oil stakeholders on the additional indicators to measure the supply chain's performance in adapting to the pandemic. The research data were collected to get an overview of the pandemicridden management of the mills. The key respondents were the Managers, Assistant Managers, Executives, Engineers, and the other representative of sustainability decision-makers of the oil mills. This study used primary data collected from two Indonesian regions named Sumatera and Kalimantan. The data collected through a questionnaire survey with 108 out of 120 were completed and accepted for further analysis. The sample size was 108 , which follows the rules of thumb for determining sample size as proposed by Roscoe (Sekaran, 2003). Roscoe (1975) proposes that sample sizes larger than 30 and less than 500 are appropriate for most research. Appropriate sample size is required for validity, and in regression analysis, many researchers acknowledge that there should be at least 10 observations per variable. This study uses three independent variables and one dependent variable; a clear rule would be to have a minimum sample size of 40 .

\section{Questionnaire Development}

A survey through questionnaire is the best method to cover a large population. Therefore, the present study developed the questionnaire as the vital device for data assemblage. The questionnaire has been carefully formulated after extensive reviewing of the extant literature (Zhang et al., 2018; Kusrini and Maswadi, 2021). It was first created in English and then was translated into Bahasa Indonesia to anticipate the nonEnglish speaking respondents. The entire questionnaire was divided into three sections $\mathrm{A}, \mathrm{B}$, and $\mathrm{C}$. Section A considered the sociodemographic variables of the respondents such as position, gender, education, employee size, and production capacity.
Section B contained the responses toward the sustainability indicators by palm oil millers in Indonesia. Section C had openended questions relating to stakeholder benefits. These variables were used in the questionnaire to ensure consistency with the previous studies of Zhang et al. (2018) and Kusrini and Maswadi (2021).

\section{Sampling Technique and Data Collection}

The responses came from the samples, out of which 108 were found complete with helpful information and were accepted for further analysis. The remaining 12 distributed questionnaires had incomplete answers and were excluded from the analysis. A "cluster sampling technique" was adopted to collect samples, as it confirms that each subgroup within the population obtains proper representation within the sample of 120 . This particular technique was consistent with (Begum et al., 2019). The response data was designed to analyze using a five-point Likert scale that ranged from the "Lowest Extent (1)" to the "Highest Extent (5)." The survey was conducted through a google form questionnaire distributed and collected over April, May, and June of 2021.

\section{Statistical Analysis}

Analysis of sustainability indicators' role in improving SSCM was derived from data analysis undertaken through IBM SPSS statistical software 21.0 to calculate data reliability, frequency distribution, Confirmatory Factor Analysis (CFA) to understand the relationships between the various elements of social, economic, and environmental factors. As suggested by (Urban and Naidoo, 2012), the Kaiser-Meyer-Olkin (KMO) test by SPSS was also used to assess the sampling adequacy and evaluate the correlations among variables. A Kaiser-Meyer-Olkin (KMO) test is used in research to determine the sampling adequacy of data that are to be used for Factor Analysis. It has been introduced Henry Kaiser in 1970 and modified by Kaiser and Rice in 1974 (Kaiser and Rice, 1974). The reliability construct was calculated separately, and data reliability for the diagnosed CFA was assessed. The variables (from section Screening of Literature) determined will be assessed for a diagnosis of CFA to identify the association sustainability indicators and SSCM performance.

As with other statistical methods, the CFA model relies upon assumptions. Procedures such as evaluating distributional characteristics of indicators and examining data for outlying cases should be conducted before CFA techniques are employed. For estimation and model identification purposes, a minimum of three observed variables for each latent variable is recommended as latent factor measured by one variable (e.g., one subscale) is not optimal and may lead to problems with an estimation as well as with construct interpretation (Bollen, 1989). The study did not conduct sensitivity analysis, as it may increase the false sense of security among managers if all pessimistic estimates of the model are optimistic and do not consider the interaction among variables. Hence, no in-depth analysis to check the model's reliability might be considered one limitation of the study. 
TABLE 4 | KMO and Bartlett's Test statistic.

\begin{tabular}{|c|c|c|c|c|c|}
\hline & & ECS & ss & ENS & KPI \\
\hline \multicolumn{6}{|c|}{ KMO and Bartlett's Test } \\
\hline \multicolumn{2}{|c|}{$\begin{array}{l}\text { Kaiser-Meyer-Olkin measure } \\
\text { of sampling adequacy. }\end{array}$} & 0.786 & 0.786 & 0.809 & 0.744 \\
\hline \multirow[t]{3}{*}{$\begin{array}{l}\text { Bartlett's test } \\
\text { of sphericity }\end{array}$} & $\begin{array}{l}\text { Approx. } \\
\text { Chi-Square }\end{array}$ & 163.156 & 163.156 & 271.667 & 317.825 \\
\hline & Df & 15 & 15 & 15 & 15 \\
\hline & Sig. & 0.000 & 0.000 & 0.000 & 0.000 \\
\hline
\end{tabular}

TABLE 5 | Reliability statistics.

\begin{tabular}{lccl}
\hline & $\begin{array}{c}\text { Cronbach's } \\
\text { Alpha }\end{array}$ & $\begin{array}{c}\text { No of } \\
\text { items }\end{array}$ & $\begin{array}{l}\text { Reliable } \\
\text { for study }\end{array}$ \\
\hline Economic sustainability & 0.776 & 6 & Yes \\
Social sustainability & 0.767 & 6 & Yes \\
Environmental sustainability & 0.839 & 6 & Yes \\
Key performance index (KPI) & 0.830 & 6 & Yes \\
\hline
\end{tabular}

\section{RESULTS}

\section{Reliability Test}

To verify the suitability of the collected data for factor analysis, the Kaiser-Meyer-Olkin Measure of Sampling Adequacy (KMO) and Bartlett's Test of Sphericity value have been investigated. Referring to Table 4, KMO value for Economy Sustainability (ECS), Social Sustainability (SS), Environmental Sustainability (ENS), and Key Performance Index (KPI) are 0.786, 0.786, 0.809, and 0.744 , respectively, while Bartlett's Test value is significant $(p$ $=0.000$ ). Therefore, factor analysis in this regard is required.

The internal consistency and reliability of the pilot survey were tested using the Cronbach's $\alpha$, which is consistent with (Ogunbiyi et al., 2014). An $\alpha$-value of the range of 0.7 is considered acceptable, and any value above 0.8 is found to be good. In the present study, data reliability with 108 sample sizes can be seen in Table 5. For ECS, the Cronbach's $\alpha$ is 0.776, SS Cronbach's $\alpha$ is 0.767 , while ENS Cronbach's $\alpha$ is 0.839 , and KPI Cronbach's $\alpha$ is 0.830 . Thus, these figures are considered good and acceptable for further study.

\section{Demographic Profile of Respondents}

Seven hundred ninety-one palm oil mills existed in Indonesia (Ministry of Energy and Mineral Resources,, 2019). Most of the Palm oil mills are situated in the Sumatra area. The demographic background of the respondents shows the percentages of the respondents (Millers) in terms of gender, education, and economic position. The majority of the executive positions are held by males ( $89.8 \%$ ), while $10.2 \%$ are females. Moreover, most respondents $(77.8 \%)$ completed their degree levels and have 2 to 3 years $(50.9 \%)$. An employee with a minimum of 2 years of experience should be considered reliable to provide information about a firm or mill, according to Dustmann and Meghir (2005). Some 501 employees and above $(60.2 \%)$ were found to be
TABLE 6 | Demographic statistics.

\begin{tabular}{llcc}
\hline Item & Measures & Frequency & Percentage \\
\hline Location & Sumatera & 56 & 51.9 \\
& Kalimantan & 35 & 32.4 \\
& Riau & 6 & 5.6 \\
& Lampung & 5 & 4.6 \\
& Papua & 3 & 2.8 \\
Years of operation & 5 to 10 & 6 & 5.6 \\
& 10 to 15 & 66 & 61.1 \\
Designation & 15 and above & 36 & 33.3 \\
& Manager & 16 & 14.8 \\
& Assistant Manager & 26 & 24.1 \\
& Executive & 12 & 11.1 \\
Gender & Engineer & 44 & 40.7 \\
& Other & 10 & 9.3 \\
Highest Education & Male & 97 & 89.8 \\
& Female & 11 & 10.2 \\
Service Length & Masters & 24 & 22.2 \\
& Bachelor Degree & 84 & 77.8 \\
& 0 to 2 years & 5 & 4.6 \\
No of Employees & 2 to 3 years & 55 & 50.9 \\
& 3 to 5 years & 30 & 27.8 \\
& 5 years and above & 18 & 16.7 \\
& 201 to 500 & 43 & 39.8 \\
& 500 and above & 65 & 60.2 \\
\hline
\end{tabular}

recruited by the surveyed mills to perform their operations (See Table 6).

\section{Frequency Distribution of Factors}

The mean and standard deviation of the palm oil miller's level of responsiveness to economic sustainability is described in Table 7. The respondents indicated that they have a "neutral" level of economic sustainability practices in these observed variables; "purchase eco-friendly materials $\left(E c_{1}\right)$ " wherein $49.1 \%$, "minimize waste disposal expenses $\left(E c_{2}\right)$ " $(46.3 \%)$, and "minimum time spent on completing an order $\left(E c_{5}\right)$ " which represent the majority of the respondents (55.6\%). About $45.4,42.6$, and $43.5 \%$ of the respondents indicated that they have a "high extent" level of economic sustainability practices which include "minimize operating costs $\left(E c_{3}\right)$ ", "on-time delivery $\left(E c_{4}\right)$ ", and "able to respond to changes in delivery schedule $\left(E c_{6}\right)$ ".

The mean and standard deviation of the palm oil miller's level of responsiveness to social sustainability is described in Table 8. The respondents indicated that they have a "neutral" level of social sustainability practices in these observed variables; "demonstrate concern for any social entity $\left(S_{1}\right)$ " wherein $49.1 \%$, "enhance community relationship (i.e., with Government or NGOs) $\left(S_{2}\right)$ " (46.3\%), and "enhance employee's job satisfaction $\left(S_{5}\right)$ " which represent the majority of the respondents $(55.6 \%)$. About 45.4, 42.6, and $43.5 \%$ of the respondents indicated that they have a "high extent" level of economic sustainability 
TABLE 7 | Responsiveness to the economic sustainability of palm oil millers.

\begin{tabular}{|c|c|c|c|c|c|c|c|c|}
\hline Independent variables & Observed variables & 1 & 2 & 3 & 4 & 5 & Mean & SD \\
\hline Economic & Purchase eco-friendly materials $\left(E C_{1}\right)$ & $2(1.9)$ & $8(7.4)$ & $53(49.1)$ & 42(38.9) & $3(2.8)$ & 3.33 & 0.736 \\
\hline \multirow[t]{4}{*}{ Sustainability } & Minimize waste disposal expenses $\left(E C_{2}\right)$ & $1(0.9)$ & $9(8.3)$ & $50(46.3)$ & $45(41.7)$ & $3(2.8)$ & 3.37 & 0.718 \\
\hline & Minimize operating costs $\left(E C_{3}\right)$ & $1(0.9)$ & 11(10.2) & $44(40.7)$ & 49(45.4) & $3(3.8)$ & 3.39 & 0.747 \\
\hline & On-time delivery $\left(E C_{4}\right)$ & $5(4.6)$ & 11(10.2) & $38(35.2)$ & $46(42.6)$ & $8(7.4)$ & 3.38 & 0.934 \\
\hline & Minimum time spent on completing order $\left(E_{C_{5}}\right)$ & $\mathrm{O}(0)$ & $5(4.6)$ & $60(55.6)$ & 38(35.2) & $5(4.6)$ & 3.40 & 0.655 \\
\hline
\end{tabular}

Numbers in bracket represent percentage.

TABLE 8 | Responsiveness to the social sustainability of palm oil millers.

\begin{tabular}{|c|c|c|c|c|c|c|c|c|}
\hline Independent variables & Observed variables & 1 & 2 & 3 & 4 & 5 & Mean & SD \\
\hline \multirow[t]{4}{*}{ Social sustainability } & Demonstrate concern for any social entity $\left(S_{1}\right)$ & $2(1.9)$ & $8(7.4)$ & $53(49.1)$ & 42(38.9) & $3(2.8)$ & 3.33 & 0.736 \\
\hline & $\begin{array}{l}\text { Enhance community relationship (i.e., with Government, } \\
\text { NGOs etc.) }\left(S_{2}\right)\end{array}$ & $1(0.9)$ & $9(8.3)$ & $50(46.3)$ & $45(41.7)$ & $3(2.8)$ & 3.37 & 0.718 \\
\hline & Minimize in employee' work-related injury/ death $\left(S_{3}\right)$ & $1(0.9)$ & $11(10.2)$ & $44(40.7)$ & $49(45.4)$ & $3(3.8)$ & 3.39 & 0.747 \\
\hline & Ensure employees' education and training program $\left(S_{4}\right)$ & $5(4.6)$ & 11(10.2) & $38(35.2)$ & $46(42.6)$ & $8(7.4)$ & 3.38 & 0.934 \\
\hline
\end{tabular}

Numbers in bracket represent percentage.

TABLE 9 | Responsiveness to the environmental sustainability of palm oil millers.

\begin{tabular}{|c|c|c|c|c|c|c|c|c|}
\hline Independent variables & Observed variables & 1 & 2 & 3 & 4 & 5 & Mean & SD \\
\hline \multirow[t]{6}{*}{ Environmental sustainability } & $\begin{array}{l}\text { Efficient use of renewable energy (rain, air, sunlight etc.) } \\
\left(E n_{1}\right)\end{array}$ & $6(5.6)$ & $17(15.7)$ & 36(33.3) & 43(39.8) & $6(5.6)$ & 3.24 & 0.96 \\
\hline & Efficient consumption of energy (electricity etc.) $\left(E n_{2}\right)$ & 13(12.0) & 20(18.5) & $27(25.0)$ & 35(32.4) & 13(12.0) & 3.14 & 1.21 \\
\hline & Minimize using of hazardous and toxic materials $\left(E n_{3}\right)$ & 10(9.3) & $34(31.5)$ & 32(29.6) & 25(23.1) & $7(6.5)$ & 2.861 & 1.08 \\
\hline & Reduce producing of solid waste $\left(E n_{4}\right)$ & $6(5.6)$ & $27(25.0)$ & $37(34.3)$ & 33(30.6) & $5(4.6)$ & 3.04 & 0.985 \\
\hline & Reduce pollution due to smoke and waste $\left(E n_{5}\right)$ & $2(1.9)$ & $7(6.5)$ & $44(40.7)$ & 40(37.0) & 15(13.9) & 3.55 & 0.880 \\
\hline & $\begin{array}{l}\text { Evaluate suppliers in terms of quality, price, availability } \\
\text { and speed }\left(E n_{6}\right)\end{array}$ & $6(5.6)$ & $35(32.4)$ & $54(50.0)$ & 13(12.0) & $16(14.8)$ & 3.69 & 0.757 \\
\hline
\end{tabular}

Numbers in bracket represent percentage.

practices which include "Minimize in employee' work-related injury/ death $\left(S_{3}\right)$ ", "ensure employees' education and training program $\left(S_{4}\right)$ ", and "enhance customer awareness of safe and healthy products $\left(S_{6}\right)$ ".

The mean and standard deviation of the palm oil miller's level of responsiveness to environmental sustainability can be referred to in Table 9. Approximately 39.8 and $32.4 \%$ of the respondents agree that they have a "high extent" in "efficient use of renewable energy (rain, air, sunlight, etc.) $\left(E n_{1}\right)$ " and "efficient consumption of energy (electricity, etc.) $\left(E n_{2}\right)$ ". On the other hand, the majority of the respondents (50\%) agreed that they are "neutral" in "evaluating suppliers in terms of quality, price, availability, and speed $\left(E n_{6}\right)$ ". About 40.7 and $34.3 \%$ of the respondents also agree that they have "neutral" in "reduce pollution due to smoke and waste $\left(E n_{5}\right)$ " and "reduce producing of solid waste $\left(E n_{4}\right)$ ". $31.5 \%$ of the respondents indicate that they have a "low extent" in "minimize using of hazardous and toxic materials $\left(E n_{3}\right)$ ".

The mean and standard deviation of the palm oil miller's Key Performance Indicators (KPI) of palm oil mill's sustainable supply chain management can be referred to in Table 10. The majority of the respondents (59.3\%) agree that they have a "high extent" of KPI in "materials usage $\left(K P I_{5}\right)$. About 44.4, 52.8, 42.6, and $37.0 \%$ also agree that they have a "high extent" in "Work in process $\left(K P I_{1}\right)$ ", "Rate of Customer Complaint and Return $\left(\mathrm{KPI}_{3}\right)$ ", Acidification Potential $\left(\mathrm{KPI}_{5}\right)$, and Physical Load Index $\left(K P I_{6}\right)$. While $43.5 \%$ of the respondents agree they are "neutral" in "EHS (environment, health, and safety)."

The mean and standard deviation distribution of the palm oil miller's level of SSCM against the sustainability indicators are summarized in Table 11. The highest mean of sustainability element is the Environmental Sustainability (4.04, sd: 0.1470), 
TABLE 10 | Key Performance Indicators (KPI) of palm oil mill's SSCM.

\begin{tabular}{|c|c|c|c|c|c|c|c|c|}
\hline Independent variables & Observed variables & 1 & 2 & 3 & 4 & 5 & Mean & SD \\
\hline Key & Work in process $\left(K P l_{1}\right)$ & $4(3.7)$ & 10(9.3) & 33(30.6) & $48(44.4)$ & 13(12.0 & 3.52 & 0.952 \\
\hline Performance & EHS (env, health and safety) expenses $\left(\mathrm{KPI}_{2}\right)$ & $1(0.9)$ & $8(7.4)$ & $47(43.5)$ & $46(42.6)$ & $6(5.6)$ & 3.44 & 0.753 \\
\hline \multirow[t]{4}{*}{ Index } & Rate of Customer Complaint and Return $\left(\mathrm{KPI}_{3}\right)$ & $O(0)$ & $2(1.9)$ & 28(25.9) & $57(52.8)$ & 21(19.4) & 3.90 & 0.723 \\
\hline & Materials usage $\left(\mathrm{KP}_{4}\right)$ & $1(0.9)$ & $4(3.7)$ & 19(17.6) & $64(59.3)$ & 20(18.5) & 3.91 & 0.768 \\
\hline & Acidification Potential $(K P / 5)$ & $\mathrm{O}(0)$ & $2(1.9)$ & $28(25.9)$ & $46(42.6)$ & 32(29.6) & 4.00 & 0.797 \\
\hline & Physical Load Index (KPI6) & $2(1.9)$ & $5(4.6)$ & $35(32.4)$ & 40(37.0) & $26(24.1)$ & 3.77 & 0.933 \\
\hline
\end{tabular}

TABLE 11 | Descriptive statistics.

\begin{tabular}{lccc}
\hline & N & Mean & SD \\
\hline Economic Sustainability & 108 & 3.42 & 0.5258 \\
Social Sustainability & 108 & 3.25 & 0.7385 \\
Environmental Sustainability & 108 & 4.04 & 0.1470 \\
Key Performance Index (KPI) & 108 & 3.76 & 0.6073 \\
\hline
\end{tabular}

indicating that the respondents mostly tend to have slightly more than "great extent" answers for this particular item. While the rest of the items only indicate that they are "neutral" in demonstrating a considerable concern toward their stakeholders while emphasizing their sustainable improvement in supply chain management of their palm oil companies in the country. The second highest mean is the Key Performance Index (3.76, sd: 0.6073), followed by Economic Sustainability (3.42, sd: 0.5258$)$ and Social Sustainability (3.25, sd: 0.7385).

\section{Confirmatory Factor Analysis}

A Confirmatory Factor Analysis (CFA) model is used to examine the hypothesized relationships between and among the constructs (factors) in the model (Figure 1). A relatively significant result was found concerning criteria implementations. The findings of the present study indicate that:

(i) A positive relationship exists between the SSCM and economic sustainability indicators.

(ii) A positive relationship exists between the SSCM and social sustainability indicators.

(iii) A positive relationship exists between the SSCM and environmental sustainability indicators.

The Pearson Correlation test is carried out to measure the association between variables. Referring to Figure 1, it can be concluded that EN (Environment) contributes the most in explaining the relationship with dependent variable or KPI (77.3\%), followed by SS (Social) (73.2\%), and EC (Economic) (70.3\%). The convergent validity test results include the coefficients and variance estimates between factors and variable loadings on the factors for each variable (refer to Table 12). Among the EC latent variables, this study found that the path coefficient of the "minimizes waste disposal expenses" obtained the highest value (0.78), followed by "minimum time spent on completing order" (0.76), "minimize operating costs"
(0.69), "able to respond to changes in delivery schedule" (0.69), "purchase eco-friendly materials" (0.68), and "on-time delivery" (0.68). Among the SS latent variables, the path coefficient of the "demonstrate concern for any social entity" and "enhance customer awareness of safe and healthy products" scored the highest value ( 0.70 respectively), followed by "enhance employees' job satisfaction” (0.66), “minimize in employee’ workrelated injury/ death" (0.65), "ensure employees' education and training program" (0.64), and "enhance community relationship (i.e., with Government, or NGOs)” (0.61).

Among the EN latent variables, the path coefficient of the "efficient consumption of energy (electricity, etc.)" scored the highest value $(0.86)$. This value is followed by "minimize using of hazardous and toxic materials" (0.84), "reduce producing of solid waste" (0.70), "evaluate suppliers in terms of quality, price, availability and speed" (0.69), "efficient use of renewable energy (rain, air, sunlight, etc.)" (0.66), and "reduce pollution due to smoke and waste" (0.56). Among the KPI latent variables, the path coefficient of the "materials usage" scored the highest (0.84), followed by "Acidification Potential" (0.83), "Physical Load Index" (0.78), "Rate of Customer Complaint and Return" (0.71), "EHS (environment, health, and safety)" (0.69), and "Work in process" (0.59).

\section{Diagnostic Test of CFA}

To govern the best fit of the model, some specific indicators were verified. Cronbach's alpha is used to determine the reliability of the factors of three dimensions. The latent variable of the model contains Cronbach's alpha values for the dimension at 0.897 . Therefore, as directed by (Nunnally and Bernstein, 1994), the reliability level for the attitude toward the dimension fulfills the critical value of 0.7 .

\section{FINDINGS}

This study has prioritized examining Indonesian palm oil mills' sustainable supply chain management practices parameters. Environmental costs, rapidity, and adaptability are more suitable as the primary indicator to express the performance of SSCM of the palm oil industry, especially during and post-pandemic periods. These findings are aligned with those of Kamble et al. (2020). The first level is related to environmental costs, specifically minimizing waste disposal expenses. Secondly, it is also highlighted that rapidity, which refers to minimizing time spent on completing orders by the surveyed palm oil 
TABLE 12 | Output summary of the confirmatory factor analysis (CFA).

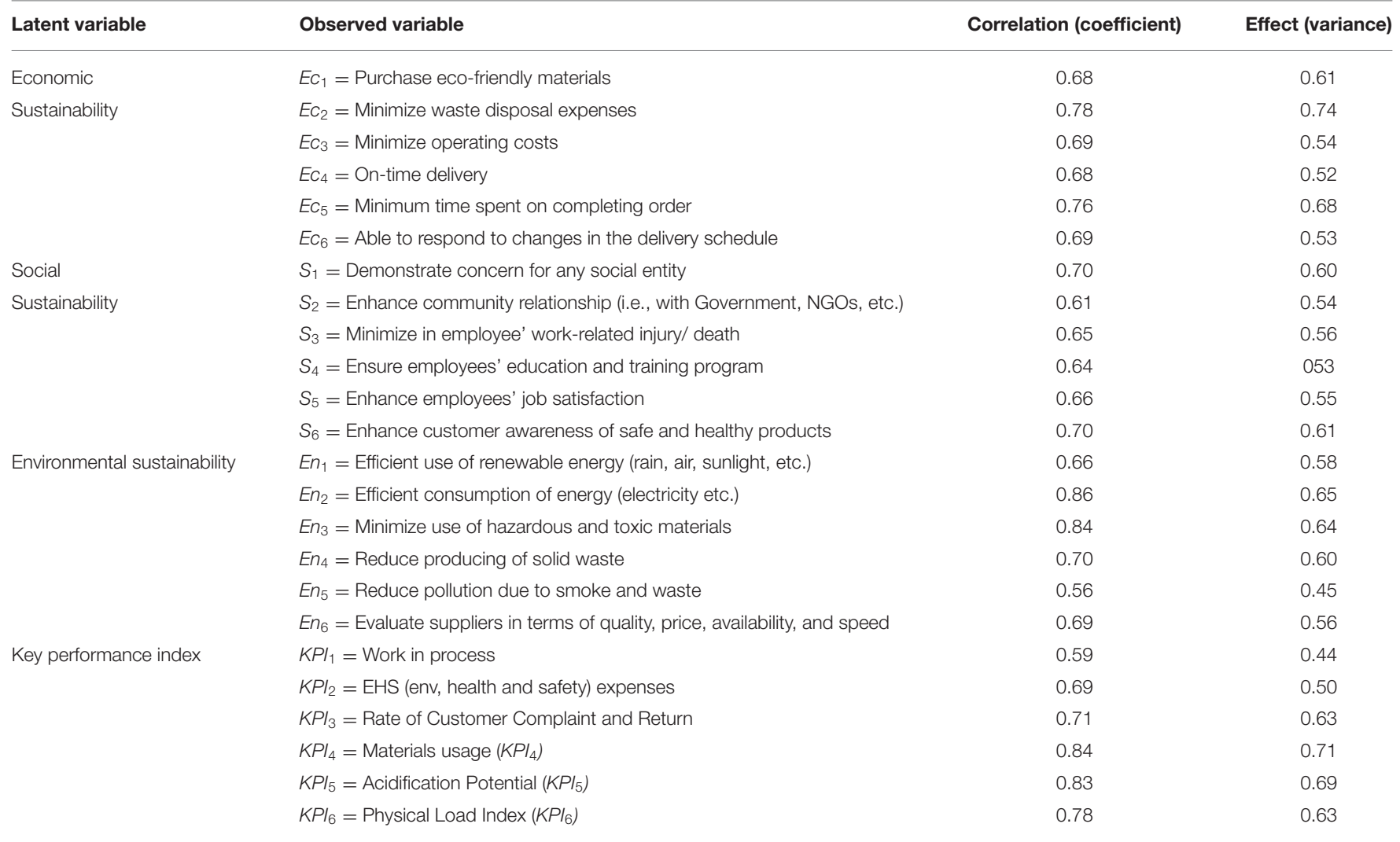

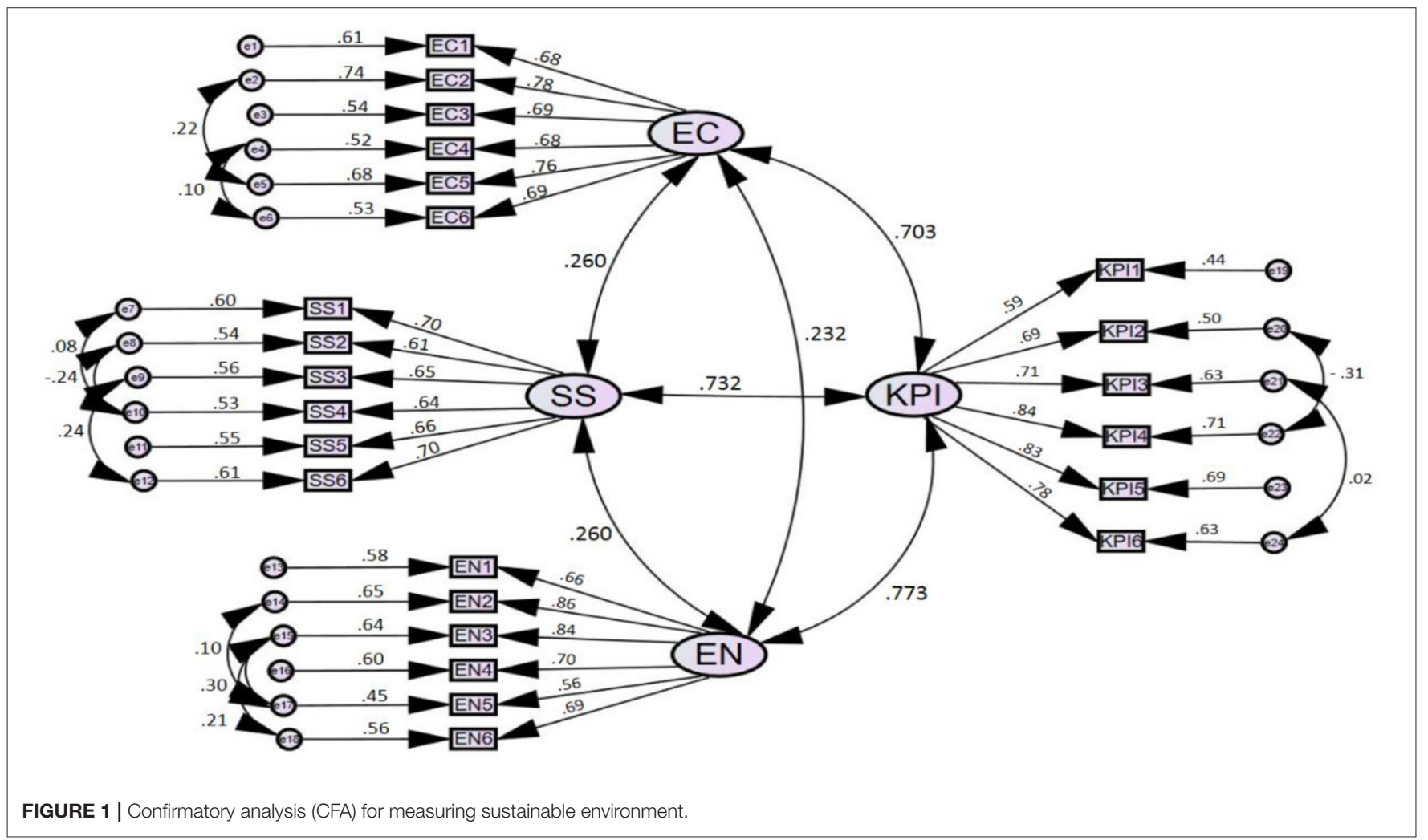


mills, also generated positive economic sustainability, leading to SSCM in Indonesia. The third-ranking level of economic sustainability is environmental costs that involve minimizing operating costs and responding to changes in delivery schedule (adaptability). The fourth level includes purchasing eco-friendly material (environmental costs) and on-time delivery (rapidity).

From a social aspect, social development, workforce development, health, and safety workforce development, as well as consumer issues are the crucial indicators for assessing the performance of SSCM, which has been reflected in the study of Zimon et al. (2019) as well to ensure sustainable operational management. Implementation of all mechanisms and protocols of COVID-19 prevention must be continued to ensure employee health and human development. The first level is related to the social development indicator of demonstrating concern for any social entity and consumer issues, including enhancing customer awareness of safe and healthy products. The notion is consistent with the findings of the study by Esfahbodi et al. (2016), Rajeev et al. (2017), and Sroufe (2017). The second level includes enhancing employees' job satisfaction (workforce development), which is consistent with the study findings by Emamisaleh et al. (2018). The third level is health and safety, explicitly minimizing employee work-related injury or death. The fourth level is workforce development or ensuring an employee's education and training program. Lastly is social development, explicitly enhancing community relationships with government, NGOs, and the like.

From an environmental aspect, energy efficiency, material efficiency, waste and emissions management, and sustainable supplier management are the most preferred indicators for assessing the performance of SSCM. The first level is energy efficiency that refers explicitly to efficient consumption of energy. The second level is the material efficiency or minimizes use of hazardous and toxic materials. The notion is consistent with the findings of the study by Saeed and Kersten (2017). The third level involves reducing the production of solid waste (waste and emissions management). The fourth level is sustainable supplier management or specifically evaluates suppliers in terms of availability, commitment, timeliness, price, and quality. The fifth level is energy efficiency (efficient use of renewable energy like rain, air, sunlight, etc.). Therefore, companies must emphasize cultivating their suppliers' sustainability performance by refining flexibility, speed, quality, and dependability (Vural, 2015).

To summarize, environmental costs, rapidity, and adaptability are the primary economic indicators. The social aspect, social development, workforce development, health, and safety workforce development, and consumer issues are the crucial social indicators. Energy efficiency, material efficiency, waste and emissions management, and sustainable supplier management are the most preferred indicators for environmental aspects. Also, these are the key findings that are suitable as the primary indicator to express the performance of SSCM of the palm oil industry, especially during and post-pandemic periods. Studies addressing supply chain issues comprehensively on determinants to enhance SSCM performance from an economic, social, and environmental perspective specifically suited for pandemic-era has not been carried out before. Thus, the baseline of SSCM assessment to compare against is peripheral.

\section{DISCUSSION}

Studies like the present one offer substantial opportunities for future sustainable palm oil supply chain management research, as it creates better managerial insights encompassing SSCM at the micro (individual mill), meso (group of mills), and macro (mill and supply chain) levels. It reveals that many millers have adequate knowledge of sustainability concerns of palm oil milling practices, especially in its supply chain. The study's findings will be helpful for the suppliers, partners, and customers of the palm oil sector to enhance the sectoral contribution to the Indonesian economy. The Indonesian government will better formulate policies to encourage the palm oil sector to perform better with the study's insights. The paper also offers functional academic implications as it uses the methodology and variables to operate and sustain in the pandemic and post-pandemic environments.

The contingency planning tools determined and discussed in this study will help the companies to survive by adjusting to the emergencies amid this pandemic. The findings infer that it is imperative to conduct customized demand drafting to assess suppliers for collaboration. Managers will benefit from the guideline to conduct continuous outreach on skills and health protocols of employees, on rapid, adaptable, and cost-effective customer service and efficient use of energy, material, waste, and emissions, and manage sustainable suppliers. The critical findings can be channeled to study the demand level and plan accordingly. At the same time, the findings can help evaluate the suppliers on the dimension of potential collaboration. The policymakers should also assist the palm oil supply chain stakeholders in resolving supply chain challenges during the pandemic and postpandemic era.

The key strength of the present study is twofold. First is the replicability offered by the study. This paper showcases adequate background and transparency of information to the audience that the research can be repeated or 'replicated' in other contexts concerning supply chain management sustainability. Future researchers can test the findings of the research and either confirm or oppose the findings. Secondly, the relevance, clarity, and exciting questions included in the questionnaire made most of the respondents agree to participate in the survey and share their opinions. The questionnaire, being customized in their preferred language, which is Bahasa Indonesia, enhanced their understandability.

This study faces a couple of limitations too. First, the expert opinions of the survey mainly covered the palm oil companies, not from their value chain. Therefore, the opinions from the customers or suppliers remained unheard. It may include other stakeholders such as suppliers and clients to ensure that the determinants are more meaningfully catering to the interests of all supply chain actors and reveal a 360-degree portrait of sustainable supply chain management. Second, the study used Cronbach's alpha test from SPSS to test the model's reliability and did not conduct an in-depth analysis such as sensitivity analysis. 
Hence, the study proposes a few cogent future research directions too. For instance, in the future, multiple-criteria decision-making (MCDM) methods or Fuzzy analytical hierarchy processes may be used to assess sustainable supply chain management practices. A sensitivity analysis can be conducted in the base model to make an in-depth analysis for future improvement. The researchers may also use a multicriteria decision-making model or other mathematical models to analyze sustainable supply chain management practices targeting reducing environmental cost, enhancing rapidity and adaptability in scheduling and using eco-friendly materials, and increasing customer and supplier satisfaction. Also, an evaluation model may be used to study companies' performance considering the criteria of supply-chain and environmental collaboration and sustainable or green supply chain management practices.

\section{CONCLUSION}

This study provides a platform on the implications of the pandemic to assess the management of a sustainable palm oil supply chain in Indonesia. It has illustrated the significant challenges concerning the crude palm oil sector regarding the social, environmental, and economic issues following the COVID-19 pandemic. It also provides insight into Indonesian palm oil mills' sustainable supply chain management practices parameters suitable for application during and post-pandemic periods. To revive and improve supply chain performance, the companies must increase adaptability to the new schedule, use more eco-friendly materials, have rapid response time, emphasize workforce development, health and safety, resolve consumer issues, and sustainable supplier management. These indicators positively ensure resilience, efficiency, and agility.

The sustainability drivers to accommodate the pandemicridden environment were evaluated from the collective opinions of extant literature. The second study objective of investigating the role of sustainability indicators to improve the SSCM of the $\mathrm{CPO}$ sector was reached using statistical analysis tools

\section{REFERENCES}

Ageron, B., Gunasekaran, A., and Spalanzani, A. (2012). Sustainable supply management: an empirical study. Int. J. Prod. Econ. 140, 168-182. doi: 10.1016/j.ijpe.2011.04.007

Azevedo, S., Carvalho, H., and Machado, V. (2011). The influence of green practices on supply chain performance: a case study approach. Transp. Res. E Logist. Transp. Rev. 47, 850-871. doi: 10.1016/j.tre.2011.05.017

Bag, S., Wood, L., Xu, L., Dhamija, P., and Kayikci, Y. (2020). Big data analytics as an operational excellence approach to enhance sustainable supply chain performance. Sustainability. 153, 104559. doi: 10.1016/j.resconrec.2019. 104559

Bai, C., Kusi-Sarpong, S., BadriAhmadi, H., and Sarkis, J. (2019). Social sustainable supplier evaluation and selection: a group decision-support approach. Int. J. Prod. Res. 57, 7046-7067. doi: 10.1080/00207543.2019.15 74042

Bai, C., and Sarkis, J. (2014). Determining and applying sustainable supplier key performance indicators. Supply Chain Manage. 19, 275-291. doi: 10.1108/SCM-12-2013-0441 and subsequent analysis of the findings. It was revealed that moving toward sustainable practices would offer more significant managerial insights and incredible benefits to CPO businesses. Such consciousness parameters can impact the rejuvenation and sustainable images of the related companies.

\section{DATA AVAILABILITY STATEMENT}

The original contributions presented in the study are included in the article/supplementary material, further inquiries can be directed to the corresponding author/s.

\section{AUTHOR CONTRIBUTIONS}

$\mathrm{NH}$ has composed the LR and methodology. KA has calculated and analyzed the responses. AL has suggested the idea. DN has helped collect the data. SW has reviewed the draft and improved. All authors contributed to the article and approved the submitted version.

\section{FUNDING}

This work was funded fully from the grant of the Frontiers Team (DSC-12032167801PRD).

\section{ACKNOWLEDGMENTS}

The research could not be possible without unconditional support and blessings from Mohammad A. Hafiz and Fatima $\mathrm{Hafiz}$, parents of the corresponding author $\mathrm{NH}$. We are grateful to Rizkihiro Danial Nasution (SKK Migas) for his genuine help translating the questionnaire in Bahasa Indonesia and reaching the OP mills representatives to obtain data. We also appreciate the wholehearted participation of the undergraduate students of IPB University, Bogor, to collect the data via google forms from the OP millers of Indonesia. Finally, special thanks to honorable editor Halima Begum and the respectable reviewers, whose advice has been useful to improve the paper.

Begum, H., Alam, A. F., Er, A. C., and Abdul Ghani, A. (2019). Environmental sustainability practices among palm oil millers. Clean Technol. Environ. Policy 21, 1979-1991. doi: 10.1007/s10098-019-01744-7

Bollen, K. A. (1989). Structural Models With Latent Variables. New York: Wiley. doi: 10.1002/9781118619179

Central Point of Expertise on Timber (2015). Sustainable Palm Derivatives in Cleaning and Personal Care. Available onlien at: https://www.gov.uk/ government/publications/cpet-sustainable-palm-oilnewsletter-july-2015. (accessed May 01, 2021)

Choi, T.-M. (2020). Innovative "Bring-Service-Near-Your-Home" operations under Corona-Virus (COVID-19/SARS-CoV-2) outbreak: can logistics become the Messiah? Transp. Res. Part E Logist. Transp. Rev. 140, 101961. doi: 10.1016/j.tre.2020.101961

Clark, W. (2007). "Sustainability science: a room of its own," in Proceedings of the National Academy of Sciences (Washington, DC), 1737-1738. doi: 10.1073/pnas.0611291104

Craighead, C., Ketchen Jr, D., and Darby, J. (2020). Pandemics and supply chain management research: toward a theoretical toolbox. Decis. Sci. 51, 838-866. doi: $10.1111 /$ deci.12468 
de Sousa Jabbour, A. B., Jabbour, C. J., Hingley, M., Vilalta-Perdomo, E. L., Ramsden, G., and Twigg, D. (2020). Sustainability of supply chains in the wake of the coronavirus (COVID-19/SARS-CoV-2) pandemic: lessons and trends. Modern Supply Chain Res. Appl. 2, 117-122. doi: 10.1108/MSCRA-05-2020-0011

Dustmann, C., and Meghir, C. (2005). Wages, experience, and seniority. Rev. Econ. Stud. 72, 77-108. doi: 10.1111/0034-6527.00325

Emamisaleh, K., Rahmani, K., and Iranzadeh, S. (2018). Sustainable supply chain management practices and sustainability. South East Asian J. Manage. 12, 282-309. doi: 10.21002/seam.v12i1.8689

Esfahbodi, A., Zhang, Y., and Watson, G. (2016). Sustainable supply chain management in emerging economies: Trade-offs between environmental and cost performance. Int. J. Prod. Econ. 181, 350-366. doi: $10.1016 /$ j.ijpe.2016.02.013

Farooq, M., Hussain, A., Masood, T., and Habib, M. (2021). Supply chain operations management in pandemics: a state-of-the-art review inspired by COVID-19. Sustainability. 13, 2504. doi: 10.3390/su13052504

Faulkner, W., Badurdeen, F., Templeton, W., and Gullet, D. (2012). Visualizing Sustainability Performance of Manufacturing Systems using Sustainable Value Stream Mapping (Sus-VSM), July 2-6. In: International Conference on Industrial Engineering and Operation Management. Istanbul, Turkey.

Govindan, K. (2018). Sustainable consumption and production in the food supply chain: a conceptual framework. Int. J. Prod. Econ. 195, 419-431. doi: $10.1016 /$ j.ijpe.2017.03.003

Grimm, J., Hofstetter, J., and Sarkis, J. (2014). Critical factors for sub-supplier management: a sustainable food supply chains perspective. Int. J. Prod. Econ. 152, 159-173. doi: 10.1016/j.ijpe.2013.12.011

Gupta, H., Kusi-Sarpong, S., and Rezaei, J. (2020). Barriers and overcoming strategies to supply chain sustainability innovation. Resour. Conserv. Recycl. 161, 104819. doi: 10.1016/j.resconrec.2020.104819

Hall, J., Matos, S., and Silvestre, B. (2012). Understanding why firms should invest in sustainable supply chains: a complexity approach. Int. J. Prod. Res. 50, 1332-1348. doi: 10.1080/00207543.2011.571930

Hobbs, J. (2020). Food supply chains during the COVID-19 pandemic. Canad. J. Agric. Econ. 68, 171-176. doi: 10.1111/cjag. 12237

Ivanov, D. (2020a). Predicting the impacts of epidemic outbreaks on global supply chains: a simulation-based analysis on the coronavirus outbreak (COVID19/SARS-CoV-2) case. Transp. Res. E Logist. Transp. Rev. 136, 101922. doi: 10.1016/j.tre.2020.101922

Ivanov, D. (2020b). Viable supply chain model: integrating agility, resilience and sustainability perspectives-lessons from and thinking beyond the COVID-19 pandemic. Anna. Oper. Res. 1-21. doi: 10.1007/s10479-020-03640-6

Ivanov, D., and Das, A. (2020). Coronavirus (COVID-19/SARS-CoV-2) and supply chain resilience: a research note. Int. J. Integ. Supply Manage. 13, 90-102. doi: 10.1504/IJISM.2020.107780

Ivanov, D., and Dolgui, A. (2020). Viability of intertwined supply networks: extending the supply chain resilience angles towards survivability. A position paper motivated by the COVID-19 outbreak. Int. J. Prod. Res. 58, 2904-2915. doi: 10.1080/00207543.2020.1750727

Kaiser, H.F., and Rice, J. (1974). "Little Jiffy, Mark Iv". Educ. Psychol. Measur. 34: 111-117. doi: 10.1177/001316447403400115

Kamble, S., Gunasekaran, A., and Gawankar, S. (2020). Achieving sustainable performance in a data-driven agriculture supply chain: a review for research and applications. Int. J. Prod. Econ. 219, 179-194. doi: 10.1016/j.ijpe.2019.05.022

Karmaker, C., Ahmed, T., Ahmed, S., Ali, S., Moktadir, M., and Kabir, G. (2021). Improving supply chain sustainability in the context of COVID-19 pandemic in an emerging economy: exploring drivers using an integrated model. Sustain. Prod. Consumpt. 26, 411-427. doi: 10.1016/j.spc.2020.09.019

Khatun, R., Reza, M. I. H., Moniruzzaman, M., and Yaakob, Z. (2017). Sustainable palm oil industry: the possibilities. Renew. Sustain. Energy Rev. 76, 608-619. doi: 10.1016/j.rser.2017.03.077

Kilpatrick, J., and Barter, L. (2020). Managing supply chain risk and disruption. Deloitte, p. 20.

Klande, S., Marten, R., and Smith, R. (2019). The palm oil industry and non-communicable diseases. Bull. World Heal. Organ. 97, 118-128. doi: 10.2471/BLT.18.220434
Kusi-Sarpong, S., Gupta, H., and Sarkis, J. (2018). A supply chain sustainability innovation framework and evaluation methodology. Int J Prod Res. 57, $1990-$ 2008. doi: $10.1080 / 00207543.2018 .1518607$

Kusrini, E., and Primadasa, R. (2018). Design of Key Performance Indicators (KPI) for Sustainable Supply Chain Management (SSCM) Palm Oil Industry in Indonesia. In: MATEC Web of Conferences (IJCAET and ISAMPE) p. 159. doi: 10.1051/matecconf/201815902068

Kusrini, N., and Maswadi. (2021). The performance improvement of sustainable palm oil supply chain management after COVID-19: priority indicators using F-AHP. Uncertain. Supply Chain Manage. 9, 227-236. doi: $10.5267 / j . u s c m .2021 .3 .010$

Li, Y., and Mathiyazhagan, K. (2018). Application of DEMATEL approach to identify the influential indicators towards sustainable supply chain adoption in the auto components manufacturing sector. J. Clean. Prod. 172, 2931-2941. doi: 10.1016/j.jclepro.2017.11.120

Lim, C., Biswas, W., and Samyudia, Y. (2015). Review of existing sustainability assessment methods for Malaysian palm oil production. In: 12th Global Conference on Sustainable Manufacturing p. 13-18. Sarawak, Malaysia: Procedia CIRP 26. doi: 10.1016/j.procir.2014.08.020

Luthra, S., Govindan, K., and andMangla, S. K. (2017). Structural model for sustainable consumption and production adoption-A greyDEMATEL based approach. Resour. Conserv. Recycl., 125, 198-207. doi: 10.1016/j.resconrec.2017.02.018

Majumdar, A., Shaw, M., and Sinha, S. (2020). COVID-19 debunks the myth of socially sustainable supply chain: a case of the clothing industry in South Asian countries. Sustain. Prod. Consumpt. 17, 176-187. doi: 10.1016/j.spc.2020. 07.001

Ministry of Energy and Mineral Resources (2019). Republic of Indonesia. Retrieved from https://www.esdm.go.id/en (accesesed March 20, 2019).

Mitchell, I. K., and Walinga, J. (2017). The creative imperative: the role of creativity, creative problem solving, and insight as key drivers for sustainability. J. Clean. Prod. 140, 1872-1884. doi: 10.1016/j.jclepro.2016.09.162

Morali, O., and Searcy, C. (2013). A review of sustainable supply chain management practices in Canada. J. Busin. Ethic. 635-658. doi: 10.1007/s10551-012-1539-4

MPOC (2020). Mitigating the impact of Covid-19 on Malaysian Palm Oil Trade. Available online at: https://mpoc.eu/webinaron-mitigating-the-impactof-covid-19-on-malaysian-palm-oil-trade/. (accessed April 23, 2021)

Munny, A. A., Ali, S. M., Kabir, G., Moktadir, M. A., Rahman, T., and Mahtab, Z. (2019). Enablers of social sustainability in the supply chain: An example of footwear industry from an emerging economy. Sustain. Prod. Consum. 20, 230-242. doi: 10.1016/j.spc.2019.07.003

Nunnally, J., and Bernstein, I. (1994). Psychometric theory. McGraw-Hill. McGrawHill.

Ogunbiyi, O., Oladapo, A., and Goulding, J. (2014). An empirical study of the impact of lean construction techniques on sustainable construction in the UK. Construct. Innov. Inform. Process Manage. 14, 88-107. doi: 10.1108/CI-08-2012-0045

Ommelna, B., Jennifer, A., and Chong, K. (2012). The potential of chitosan in suppressing Ganoderma boninense infection in oil-palm seedlings. J. Sustain. Sci. Manag. 7, 186-192.

Papilo, P., Marimin, H.ambali E., and Sitanggang, I. S. (2018). Sustainability index assessment of palm oil-based bioenergy in Indonesia. J. Clean Prod. 2018; 196:808-820. doi: 10.1016/j.jclepro.2018.06.072

Rajeev, A., Pati, R. K., Padhi, S., and Govindan, K. (2017). Evolution of sustainability in supply chain management: a literature review. J. Clean. Prod. 162, 299-314. doi: 10.1016/j.jclepro.2017.05.026

Raut, R. D., Narkhede, B., and Gardas, B. B. (2017). To identify the critical success factors of sustainable supply chain management practices in the context of oil and gas industries: ISM approach. Renew. Sustain. Energy Rev. 68, 33-47. doi: $10.1016 /$ j.rser.2016.09.067

Remko van, H. (2020). Research Opportunities for a more resilient post-COVID-19 supply chain - closing the gap between research findings and industry practice. Int. J. Oper. Prod. Manag. 40, 341-355. doi: 10.1108/IJOPM-03-2020-0165

Roscoe, J. T. (1975). Fundamental Research Statistics for the Behavioral Sciences. (2nd Ed.). New York: Holt, Rinehart, and Winston. 
Saeed, M., and Kersten, W. (2017). Supply chain sustainability performance indicators: a content analysis based on published standards and guidelines. Logist. Res. 10, 1-9. doi: 10.23773/2017_12

Sajjad, A., Eweje, G., and Tappin, D. (2020). Managerial perspectives on drivers for and barriers to sustainable supply chain management implementation: Evidence from New Zealand. Bus. Strat. Environ. 29, 592-604. doi: 10.1002/bse.2389

Sekaran, U. (2003). Research methods for business: A skill-building approach. John Wiley and Sons.

Seuring, S., and Müller, M. (2008). From a literature review to a conceptual framework for sustainable supply chain management. J Clean Prod. 16, 16991710. doi: 10.1016/j.jclepro.2008.04.020

Sharma, M., Luthra, S., Joshi, S., and Kumar, A. (2020). Developing a framework for enhancing the survivability of sustainable supply chains during and post-COVID-19 pandemic. Int. J. Logist. Res. Appl. 1-21. doi: 10.1080/13675567.2020.1810213

Sparks, D. (2014). Combining Sustainable Value Stream Mapping and Simulation To Assess Manufacturing Supply Chain Network Performance. Thesis and Dissertations. Kentucky: University of Kentucky UKnowledge.

Sroufe, R. (2017). Integration and Organizational Change Towards Sustainability. J. Clean. Prod. 162, 315-329. doi: 10.1016/j.jclepro.2017.05.180

Statista (2020). Statista Leading producers of palm oil worldwide from 2012/13 to 2019/20. Available online at: https://www.statista.com/statistics/856231/palmoil-top-globalproducers/. (accessed April 29, 2021)

Sutawidjaya, A., Nawangsar, L., and Nor, N. (2021). Life cycle assessment: study linkage between environment supply chain management and sustainability of supply chain. Uncert. Supply Chain Manage. 9, 179-186. doi: $10.5267 /$ j.uscm.2020.10.003

Tseng, M., Lim, M. K., and Wong, W. (2015). Sustainable supply chain management: a closed-loop network hierarchical approach. Sustain. Supply Chain Manage. 115, 436-461. doi: 10.1108/IMDS-10-2014-0319

Tseng, M.-L., Lim, M. K., and Wu, K.-J. (2019). Improving the benefits and costs on sustainable supply chain finance under uncertainty. Int. J. Prod. Econ. 218, 308-321. doi: 10.1016/j.ijpe.2019.06.017

Urban, B., and Naidoo, R. (2012). Business sustainability: empirical evidence on operational skills in SMEs in South Africa. J. Small Busi. Entrepr. Dev. 146-163. doi: 10.1108/14626001211196451

Vargas, J. R. C., Mantilla, C. E. M., and de Sousa Jabbour, A. B. L. (2018). Enablers of sustainable supply chain management and its effect on competitive advantage in the Colombian context. Resour. Conserv. Recycl. 139, 237-250. doi: 10.1016/j.resconrec.2018.08.018
Veleva, V., and Ellenbecker, M. (2001). Indicator of Sustainable production: framework and methodology. J. Clean. Prod. 9, 519-549. doi: 10.1016/S0959-6526(01)00010-5

Vural, C. A. (2015). Sustainable demand chain management: An alternative perspective for sustainability in the supply chain. Proc. Soc. Behav. Sci. 207, 262-273. doi: 10.1016/j.sbspro.2015.10.095

World Commission on Environment and Development (1987). Report of the World Commission on Environment and Development: Our common future. (Accessed Feb 10)

Zailani, S., Jeyaraman, K., Vengadasan, G., and Premkumar, R. (2012). Sustainable supply chain management (SSCM) in Malaysia: a survey. Int. J. Prod. Econ. 330-340. doi: 10.1016/j.ijpe.2012.02.008

Zeng, H., Chen, X., Xiao, X., and Zhou, Z. (2017). Institutional pressures, sustainable supply chain management, and circular economy capability: Empirical evidence from Chinese eco-industrial park firms. J. Clean. Prod. 155, 54-65. doi: 10.1016/j.jclepro.2016.10.093

Zhang, M., Tse, Y. K., Doherty, B., Li, S., and Akhtar, P. (2018). Sustainable Supply Chain Management: confirmation of a higher-order model. Conserv. Recycl. 128, 206-221. doi: 10.1016/j.resconrec.2016.06.015

Zimon, D., Tyan, J., and Sroufe, R. (2019). Implementing sustainable supply chain management: reactive, cooperative, and dynamic models. Sustainability 11, 7227. doi: $10.3390 /$ su11247227

Conflict of Interest: The authors declare that the research was conducted in the absence of any commercial or financial relationships that could be construed as a potential conflict of interest.

Publisher's Note: All claims expressed in this article are solely those of the authors and do not necessarily represent those of their affiliated organizations, or those of the publisher, the editors and the reviewers. Any product that may be evaluated in this article, or claim that may be made by its manufacturer, is not guaranteed or endorsed by the publisher.

Copyright (C) 2022 Hafiz, Azmi, Nimfa, Latiff and Wahab. This is an open-access article distributed under the terms of the Creative Commons Attribution License (CC $B Y)$. The use, distribution or reproduction in other forums is permitted, provided the original author(s) and the copyright owner(s) are credited and that the original publication in this journal is cited, in accordance with accepted academic practice. No use, distribution or reproduction is permitted which does not comply with these terms. 